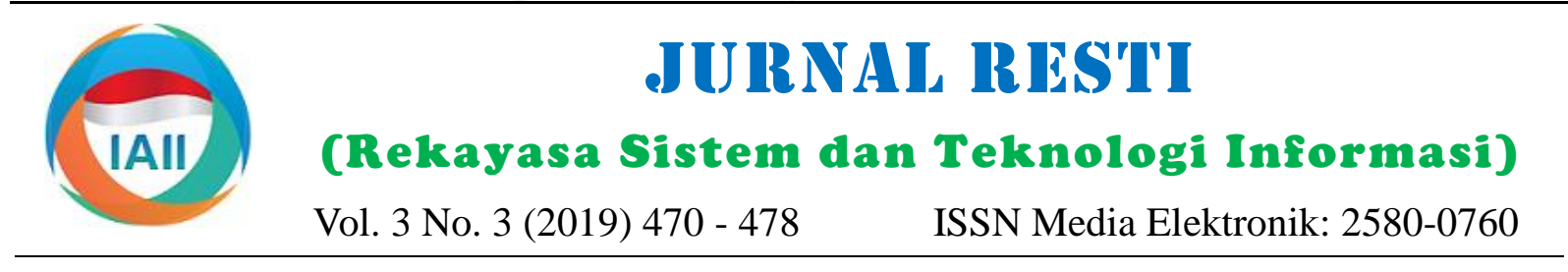

\title{
Pengembangan E-Authentic Asessment Berbasis PBL untuk Meningkatkan Kompetensi Mahasiswa dalam Pembelajaran Jaringan Komputer
}

\author{
Ambiyar $^{1}$, Raimon Efendi ${ }^{2}$,Waskito ${ }^{3}$, Surfa $_{\text {Yondri }}{ }^{4}$, Yuyun Irawati $^{5}$ \\ ${ }_{1,3,5}$ Fakultas Teknik, Universitas Negeri Padang \\ ${ }^{2}$ Fakultas Ilmu Komputer, Universitas Dharmas Indonesia \\ ${ }^{4}$ Teknik Listrik, Politeknik Negeri Padang \\ ${ }^{1}$ ambiyar@ft.unp.ac.id, ${ }^{2}$ raimon.efendi@gmail.com, ${ }^{3}$ waskito@ft.unp.ac.id, \\ ${ }^{4}$ surfa_yondri@yahoo.com, ${ }_{2}^{5}$ yuyunirawati1440@gmail.com
}

\begin{abstract}
This study aims to develop authentic online assessment instruments based on problem based learning. Authentic assessment instruments will be accessed online in computer network learning to measure student competencies effectively and efficiently. Type of research is research and development and used refer to the $4 \mathrm{D}$ model (define, design, develop, disseminate). The analysis technique uses the Aiken'V test, and validity uses expert testing and Focus Group Discussion (FGD). The practicality test is carried out by applying the product to students in the form of a product practicality questionnaire and to test the effectiveness using basic time series design. Validity test results show the RPS and instruments developed are valid with Aiken's V values of 0.708 and 0.716. Practicality test results on the practicality test by lecturers and students on the RPS were 93\% and authentic assessment $91 \%$. Effectiveness test results with time series analysis were $38 \%$ with the effective category. The implication of the study is that there is a positive effect on learning outcomes, the value of students completeness increases and the gain score test is 0.38 in the medium category. The findings of this study have resulted in eauthentic assessment instruments with valid, practical and effective categories.
\end{abstract}

Keywords: E-Authentic Assessment, R\&D, Computer Networks, Competence

\begin{abstract}
Abstrak
Penelitian ini bertujuan untuk mengembangkan instrumen authentic assesment online berbasis problem based learning. Instrumen authentic asessment akan diakses secara online dalam pembelajaran jaringan komputer untuk mengukur kompetensi mahasiswa secara efektif dan efisien. Jenis penelitian ini adalah penelitian dan pengembangan $(R \& D)$, metode dan prosedur pengembangan yang digunakan merujuk pada model $4 \mathrm{D}$ (define, design,develop,disseminate). Teknik analisis menggunanakan uji Aiken'V, dan validitas menggunakan uji pakar dan Focus Group Discussion (FGD). Uji kepraktisan dilakukan penerapan produk ke mahasiswa dalam bentuk angket kepraktisan produk dan untuk menguji efektifitas menggunakan basic time series design. Hasil uji validitas menunjukan RPS dan instrumen yang dikembangkan valid dengan nilai Aiken's V sebesar 0,708 dan 0,716. Hasil uji praktikalitas pada uji kepraktisan oleh dosen dan mahasiswa terhadap RPS adalah $93 \%$ dan authentic assesment 91\%. Hasil uji efektivitas dengan analisis time series adalah $38 \%$ dengan kategori efektif. Implikasi penelitian ini adalah adanya pengaruh positif terhadap hasil pembelajaran, nilai ketuntasan peserta didik meningkat serta didapatkan uji gain score 0.38 dengan kategori sedang. Temuan penelitian ini adalah dihasilkannya instrumen $e$-authentic assesment dengan kategori valid, praktis dan efektif.
\end{abstract}

Kata Kunci: E-Authentic Asessment, R \& D, Jaringan Komputer, Kompetensi

(C) 2019 Jurnal RESTI

Diterima Redaksi : 06-11-2019| Selesai Revisi : 26-11-2019 | Diterbitkan Online : 10-12-2019 


\section{Pendahuluan}

Perubahan paradigma pendidikan di Abad 21 juga berpengaruh kepada konsep penilaian pendidikan. Konsep penilaian pendidikan saat ini menunjukkan arah yang lebih luas. Berdasarkan paradigma itulah istilah assessment muncul. Proses assessment mencakup sejumlah bukti-bukti yang menunjukkan pencapaian hasil belajar peserta didik. Assessment ini dilaksanakan secara terpadu dengan kegiatan pembelajaran sehingga disebut sebagai penilaian berbasis kompetensi. Penilaian dilakukan dengan berbagai cara seperti pengumpulan kerja peserta didik (portofolio), hasil karya (product), penugasan (problem), kinerja (performance), dan tes tertulis (paper and pencil). Dosen menilai kompetensi dan hasil belajar peserta didik berdasarkan tingkat pencapaian prestasi peserta didik. Penilaian demikianlah yang disebut authentic assessment (penilaian otentik).

Penilaian pembelajaran khususnya dalam pembelajaran Jaringan Komputer selama ini cenderung lebih difokuskan pada penilaian ranah kognitif saja sehingga ranah afektif dan ranah psikomotoriknya kurang diperhatikan. Padahal kenyataannya pembelajaran jaringan komputer di Prodi Teknik Informatika menuntut keterlibatan peserta didik secara aktif dan bertujuan agar penguasaan dari kognitif, afektif, psikomotorik terbentuk pada diri peserta didik [1]. Oleh karena itu alat ukur hasil belajarnya tidak cukup jika hanya dengan tes kognitif berupa tes obyektif atau subyektif saja, dengan cara tersebut keterampilan mahasiswa melakukan percobaan maupun menciptakan suatu hasil karya belum dapat diungkap. Demikian pula tentang aktivitas mahasiswa selama mengerjakan tugas dari dosen, baik berupa tugas individu maupun kelompok.

Berdasarkan kondisi dan realita yang ditemukan di lapangan, terlihat ada kesenjangan antara harapan pembelajaran Jaringan komputer dengan teknik penilaiannya. Hasil temuan di lapangan, asesmen atau penilaian yang dilakukan oleh dosen pada materi jaringan komputer adalah penilaian tradisional berupa
soal-soal pilihan ganda. Soal-soal tersebut hanya memuat aspek kognitif jenjang $\mathrm{C} 1-\mathrm{C} 3$, padahal asesmen abad ke-21 seharusnya lebih difokuskan kepada asesmen autentik yang mengukur baik aspek kognitif, afektif, maupun psikomotor [2].

Sebagai upaya memperbaiki kondisi pembelajaran Jaringan Komputer, khususnya dalam hal mengungkap berfokus pada kemampuan untuk menghadapi penilaian yang dilakukan oleh dosen, oleh karena itu kehidupan yang semakin kompleks dan penilaian otentik perlu dilaksanakan. Dengan demikian lingkungan kerja di abad ke-21. Salah satu elemen diharapkan dapat meningkatkan mutu pembelajaran ini menunjukkan bahwa berpikir kritis, kreativitas Jaringan Komputer dalam proses penilaian dalam dalam berinovasi, komunikasi dan kolaborasi; menjadi pembelajaran yang dapat mengungkap ketiga ranah, tuntutan untuk dimiliki mahasiswa sebagai bekal yaitu kognitif, afektif dan psikomotorik pada peserta menghadapi tantangan kehidupan. Keterampilan abad didik.
Urgensi peneltian ini adalah sulitnya dosen memaknai mengembangkan dan menggunakan penilaian autentik asessment di Perguruan Tinggi. Banyak dosen yang memaknai bahwa penggunaan authentic asessment hanya sebagai penggunaan asesmen alternatif yang bentuknya authentic asessment. Namun menurut Torulf Palm [3] asesmen kinerja atau asesmen alternatif tidak menjadi otentik jika permasalahan yang dinilai bukan masalah yang nyata. Menurut Chang dan Chiu [4] Format authentic asessment dapat dikembangkan berupa soal-soal multiple-choice, open-ended, dan hands-on test untuk memperlihatkan evaluasi kognitif mahasiswa dengan memperhatikan karakteritik menyusun dokumen authentic asessment dengan baik karena penilaian otentik baru dikenal secara teori dan konsep. Tidak semua dosen mampu mengalihkannya ke dalam prosedur penilaian kelas sehari-hari. Bahkan terdapat sebagian kecil dosen yang tidak mengetahui apa dan bagaimana format atau bentuk penilaian otentik, apa manfaat yang diperoleh dan komponenkomponen apa saja yang harus ada dalam sebuah instrumen penilaian otentik. Penelitian ini akan melakukan analisis terhadap penggunaan penilaian Tantangan dan peluang industri 4.0 di Abad 21 mendorong inovasi dan kreasi di bidang pendidikan. Tantangan pendidikan vokasi semakin kompleks dengan industri 4.0. Brown, Kirpal, \& Rauner [5] menyatakan bahwa pelatihan kejuruan dan akuisisi keterampilan sangat mempengaruhi pengembangan identitas seseorang terkait dengan pekerjaan. Selanjutnya, Lomovtseva dan Edmond [6],[7] menjelaskan, pendidikan merupakan tempat menempa kematangan dan keterampilan seseorang sehingga tidak bisa hanya dibebankan kepada suatu kelompok melainkan menjadi tanggung jawab bersama. Pendidikan juga diarahkan untuk meningkatkan emandirian individu sesuai dengan kompetensi yang [8]. Penyiapan beberapa kompetensi harus dan mau bekerja sesuai dengan bidang keahliannya [9]. Perubahan paradigma pembelajaran ini disesuaikan dengan ciri abad 21. Salah satu elemen kunci dari pembelajaran abad ke-21 adalah learning and innovation skills atau kecakapan pembelajaran dan inovasi, yaitu 4C, critical thinking, communication, collaboration, dan creativity. Kemampuan 4C ini 21 merupakan keterampilan yang semakin menuntut keotentikanya, namun, tidak semua dosen mampu pendidikan karena pendidikan vokasi merupakan 
kreativitas, ketekunan dan pemecahan masalah yang Assesment yang disimpan dalam format elektronik dan dikombinasikan dengan berkinerja dengan baik terhubung dengan jaringan internet [17]. Portofolio sebagai bagian dari tim [10]. Kreativitas dalam berbasis website memiliki persamaan isi dengan kerangka ini sejalan dengan tujuan pendidikan Authentic Assesment biasa, hanya saja informasi itu nasional dalam Pasal 3 Undang-Undang No. 20 Tahun dikumpulkan, disajikan, dan disusun secara elektronik 2003 tentang Sistem Pendidikan Nasional, yang berbasis komputer. Dengan adanya kemajuan teknologi menegaskan bahwa pendidikan nasional bertujuan informasi saat ini, setiap mahasiswa dapat menyimpan untuk mengembangkan potensi peserta didik agar dan menampilkan karya tulis, tugas, karya seni, menjadi manusia yang salah satunya adalah kreatif.

Penguasaan konsep menurut Bloom adalah kemampuan presentasi multimedia dalam bentuk teks, grafik, suara, dan video dalam satu dokumen yang saling berkaitan.

menangkap pengertian-pengertian seperti mampu Pembelajaran Abad 21 menuntut kurikulum dalam mengungkapkan suatu materi yang disajikan ke dalam pembelajaran Jaringan Komputer memberi pengalaman bentuk yang lebih dipahami, mampu memberikan belajar secara langsung, sangat ditekankan melalui interpretasi dan mampu mengaplikasikannya [11]. penggunaan dan pengembangan ketrampilan proses, Hirarki keterampilan berpikir pada Taksonomi Bloom dan sikap ilmiah dengan tujuan untuk memahami Revisi yakni dari keterampilan berpikir tingkat rendah konsep-konsep dan mampu memecahkan masalah. sampai pada keterampilan berpikir tingkat tinggi, yaitu: Dengan demikian, diperlukan upaya yang tepat untuk C1-mengingat, C2-memahami, C3- mengaplikasikan, meningkatkan hasil belajar mahasiswa, salah satu C4-menganalisis, C5-mengevaluasi, dan C6-mencipta. upayanya adalah dengan model Pembelajaran Berbasis C1, C2, dan C3 dikategorikan sebagai keterampilan Masalah Menurut Arends [18], Problem Based berpikir tingkat rendah; sedangkan C4, C5, dan C6 Learning atau pembelajaran berbasis masalah dikategorikan dalam keterampilan berpikir tingkat merupakan model pembelajaran yang menggunakan tinggi [12].

Salah satu konsep yang dipelajari dalam Mata Kuliah Jaringan Komputer adalah mengenai Wireless Network. Materi Wireless merupakan materi yang luas dan dalam, walaupun sudah cukup familiar di telinga mahasiswa. Seberapa luas dan dalam mahasiswa dapat memahami materi wireless ini bergantung pada cara mahasiswa menggali konsep-konsep mengenai wireless [13]. Hal ini menjadi menarik untuk dipelajari mahasiswa dengan menggunakan model Problem based learning, karena Problem based learning meminta mahasiswa untuk menyelidiki isu-isu dan topik mengenai masalah dunia nyata sambil mengintegrasikan materi pelajaran lintas kurikulum. Selain itu, salah satu unsur penting dalam merancang proyek adalah keaslian (authenticity) yaitu memiliki konteks dunia nyata, tugas dan alat-alat, standar kualitas, atau dampak, atau yang menjadi keprihatinan bagi mahasiswa, menarik, dan isu-isu dalam kehidupan mereka [14].

Pelaksanaan kegiatan pembelajaran tidak terlepas dari kegiatan penilaian (Assesment), hal ini sesuai dengan salah satu prinsip authentic asessment yaitu proses penilaian harus merupakan bagian yang yang tidak terpisahkan dari proses pembelajaran, bukan kegiatan terpisan dari proses pembelajaran [15]. Penilaian autentik merupakan penilaian kinerja, namun tidak semua penilaian kinerja merupakan penilaian autentik [16]. Keberhasilan dalam suatu pembelajaran dapat diketahui dengan penilaian/asesmen.

Media penilaian E-Authentic Assesment dapat menjadi solusi alternatif atas permasalahan di atas. Authentic Assesment jenis ini dinamakan authentic asessment berbasis website, yaitu sebuah dokumen Authentic pendekatan masalah yang autentik sehingga mahasiswa dapat menyusun pengetahuannya sendiri, menumbuh kembangkan ketrampilan yang lebih tinggi dan inkuiri, memandirikan mahasiswa, dan meningkatkan kepercayaan diri sendiri. Model ini bercirikan penggunaan masalah kehidupan nyata sebagai sesuatu yang harus dipelajari oleh mahasiswa untuk melatih dan meningkatkan ketrampilan berpikir kritis memecahkan masalah, serta mendapat pengetahuan tentang konsep-konsep penting. Pendekatan pembelajaran ini mengutamakan kepada proses belajar, dengan tugas dosen harus memfokuskan diri untuk membantu mahasiswa.

Penilaian otentik menekankan keterampilan dan kompetensi spesifik untuk menerapkan keterampilan dan pengetahuan yang sudah dikuasai [15]. Authentic asessment merupakan suatu bentuk penilaian dimana mahasiswa diminta untuk menunjukkan tugas nyata yang memperlihatkan penerapan pengetahuan dan keterampilan yang penting dan bermakna. Melalui authentic asessment setiap kegiatan yang dilakukan oleh mahasiswa dalam pembelajaran berbasis masalah, baik mulai dari fase perencanaan sampai menghasilkan suatu produk dapat dinilai secara nyata [19]. Namun, penilaian secara nyata kemampuan yang dimiliki oleh mahasiswa selama proses pembelajaran dapat dilakukan dengan authentic asessment.

Penilaian hasil belajar yang dipadukan dengan model pembelajaran PBL, dapat dilakukan dengan cara menggunakan penilaian E-Authentic Assesment. Melalui E-Authentic Assesment hasil belajar dalam hal pengetahuan, sikap (sikap spiritual dan sikap sosial) dan ketrampilan dapat di akses melalui jurnal belajar pada setiap akhir pertemuan. Tugas mahasiswa dalam 
E-Authentic Assesment ini yaitu membuat jurnal belajar expert appraisal berupa proses untuk menilai dan refleksi diri yang nantinya di posting pada rancangan produk instrumen asesmen kinerja atas dasar portofolio berbasis website pada setiap kali pertemuan. rasional ahli. Produk e-authentic assessment Tujuan penelitian ini yaitu mengembangkan portofolio pembelajaran jaringan computer yang disusun peneliti berbasis website sebagai rangkaian proses penilaian divalidasi oleh ahli (judgement expert). Selanjutnya yang seharusnya dilakukan oleh dosen di kelas.

\section{Metode Penelitian}

Penelitian ini merupakan jenis penelitian dan pengembangan (Research and Development). Adapun model penelitian dan pengembangan pendidikan Developmental testing merupakan kegiatan uji (Research and Development) yang dilakukan rancangan produk pada sasaran subjek yang mengadopsi pada model pengembangan 4-D (Four-D). sesungguhnya. pada tahap developmental testing Model penelitian dan pengembangan Four-D penilaian dilakukan atas dasar data empiris, yaitu hasil dikembangkan oleh Sivasailam Thiagarajan, Dorothy S. uji instrumen pada subjek nyata di lapangan. Tahapan Semmel dan Melvyn I. Semmel (1974) dengan tahapan uji coba dan revisi merupakan tahapan yang penting penelitian yaitu, define, design, develop, dan dalam tahapan penelitian ini. Pada tahapan ini, produk dissemination. Singgih \& Palupi (2013) menyatakan diuji di lapangan secara langsung dan didapatkan data model 4-D mudah dipahami serta mempunyai langkah- empiris yang nantinya digunakan dalam tahapan revisi. langkah atau tahapan yang sistematis.

\subsection{Define}

Uji instrumen dilakukan untuk mengetahui apakah produk instrumen asesmen kinerja bisa digunakan untuk mengukur kinerja mahasiswa dalam proses

Tahap define terdiri dari dua kegiatan pokok, yaitu pembelajaran.

analisis kebutuhan dan kajian literatur. Pada tahap analisis kebutuhan dilakukan penelitian untuk mendefinisikan kebutuhan dalam pengembangan, syarat-syarat pengembangan, dan penentuan model pengembangan yang akan digunakan sesuai dengan tujuan pengembangan. Pada penelitian awal ini dilakukan analisis kondisi lapangan, kondisi yang ada mencangkup: (a) kondisi produk yang sudah ada sebagai bahan perbandingan atau bahan dasar untuk Penelitian pengembangan instrumen e-authentic pengembangan produk, (b) kondisi pengguna, seperti asessment ini terbagi menjadi tiga tahapan, yaitu prodi, dosen, mahasiswa, atau pengguna lainnya, (c) tahapan pengembangan instrumen, tahapan kondisi faktor-faktor pendukung dan penghambat validasi dan uji coba. Instrumen dan tahapan pengembangan dan penggunaan dari produk yang akan aplikasi instrumen. Pada tahapan pengembangan dan dihasilkan

\subsection{Design}

Tahap design penelitian betujuan untuk membuat yang digunakan adalah instrumen tes tertulis dan produk awal rancangan (prototype) e-authentic instrumen tes kinerja yang sudah teruji valid dan assessment. Pengembangan e-authentic assessment. reliabel serta worksheet mahasiswa.

dilakukan dengan membuat kerangka konseptual instrumen sesuai dengan analisis kurikulum dan materi. Tahapan design dilakukan melalui dua pokok tahapan, yaitu perencanaan dan perancangan. Tujuan yang ingin dicapai yaitu untuk memfokuskan aspek apa saja yang ditampilkan dalam indikator keterampilan pada butir asesmen. Perencanaan instrumen dibuat berdasarkan urutan langkah kerja yang dilakukan dalam pembelajaran jaringan komputer.

\subsection{Develop}

Tahap develop dilakukan validasi, penilaian produk dan uji produk. Thiagarajan (1974) membagi tahap pengembangan dalam dua langkah kegiatan yaitu, (1) expert appraisal, dan (2) developmental testing. Tahap

Penelitian dilaksanakan di Universitas Dharmas Indonesia, Fakultas Ilmu Komputer Prodi Teknik Informatika. Penggunaan sampel penelitian terdapat pada tahapan validasi dan uji coba instrumen yang dikembangkan, dan pada tahapan aplikasi dengan menggunakan instrumen yang telah valid dan reliabel.

tahapan validasi dan uji coba, instrumen penelitian yang digunakan adalah lembar validasi instrumen. Sedangkan pada tahapan aplikasi, instrumen yang digunakan adalah instrumen tes tertulis dan
instrumen tes kinerja yang sudah teruji valid dan Pada penelitian pengembangan instrumen penilaian otentik ini, produk yang dihasilkan berupa instrumen tes berbasis web untuk menilai pengetahuan dan instrumen tes kinerja untuk menilai keterampilan praktikum mahasiswa. Instrumen penilaian dikembangkan pada tahap pengembangan instrumen kemudian divalidasi dan uji coba pada tahap validasi dan uji coba. Setelah instrumen valid dan reliabel, maka instrumen diaplikasikan langsung kepada mahasiswa Fakultas Ilmu Komputer Prodi Teknik Informatika pada tahap aplikasi. 


\section{Hasil dan Pembahasan}

Pengembangan e-authentic asessmen dalam pembelajaran jaringan komputer dilakukan untuk menghasilkan instrumen yang valid, praktis dan efektif dalam penggunaanya. Penggunaan instrumen yang telah teruji diharapkan dapat meningkatkan respons mahasiswa, dan respons pendidik, sehingga proses pembelajaran mampu memnghasilkan learning outcome yang bermutu. Pengumpulan data dilakukan dengan menggunakan lembar observasi keterampilan praktis, instrumen penilaian otentik dan kuesioner. Pengumpulan data telah dilakukan di Program Studi Teknik Informatika Universitas Dharmas Indonesia pada bulan Maret hingga September 2019 dengan pemilihan materi routing dan wireless untuk mahasiswa TI semester 5. Tahapan yang dilakukan untuk menghasilkan produk instrumen $e$-authentic asessment dalam pembelajaran pembelajaran jaringan komputer adalah:

\subsection{Hasil Need Analysis dalam proses Define}

Hasil analisis kurikulum (curriculum analysis) yang 3.2 Design E-Authentic Asessment

telah diterapkan di lembaga Pendidikan tinggi Prodi Penilaian autentik dapat diakses melalui alamat: Teknik Informatika Fakultas Ilmu Komputer https://raimone-learning.com. Fitur utama dalam $e$ Universitas Dharmas Indonesia diketahui melalui authentic asessment ini adalah fitur rubrik authentic wawancara yang dilakukan dengan ketua Program asessment. Dalam formulir penilaian ini, instrumen Studi Teknik Informatika dan Dekan Fakultas Ilmu input dosen yang akan digunakan sebagai referensi Komputer, para dosen pengajar dan teknisi labotorium. dalam penilaian mahasiswa, dalam pembelajaran Prioiritas/kebutuhan dosen dalam peningkatan kualitan jaringan komputer terdapat beberapa kriteria yang pembelajaran jaringan komputer terlihat bahwa dosen digunakan sebagai pedoman dalam penilaian. ada memiliki ekspektasi yang tinggi terhadap proses beberapa langkah yang harus diambil untuk pembelajaran dan proses authentic asesmen berbasis mendapatkan hasil pada e-authentic asessment. Untuk problem based learning. Pada tahap define ini mendapatkan hasil menggunakan e-authentic dilakukan literature review tentang model asessment, maka proses yang pertama dilakukan dosen pembelajaran berbasis masalah yang terintegrasi adalah menginput Instrumen penilaian (autenthic dengan proses penilaian otentik berbasis online. asessment). Intrumen ini di input dengan tahap-tahap Ekspektasi dosen terhadap proses pembelajaran sebagai berikut:

diharapkan mampu meningkatkan kompetensi 1. Entri Topik

mahasiswa terutama kompetensi pembelajaran abad ke- Form entri topik ini digunakan untuk melakukan input 21 (critical thinking, communication, collaboration, topik kompetensi/topik pembelajaran, topik disesuaikan creativity). Gambaran descrapancy antara keadaan saat dengan mata kuliah dan telah tercantum dalam Rencana ini dan prioiritas/kebutuhan dosen dan mahasiswa Pembelajaran Semester (RPS) seperti terlihat pada adalah 2,83 yang dapat diasumsikan bahwa dosen gambar 2 .

membutuhkan sebuah model pembelajaran yang inovatif dalam menggali kemampuan peserta didik dalam proses pembelajaran, seperti terlihat pada gambar 1.

Analisis kurikulum juga dibahas pada kegiatan Focus Group Discussion (FGD), dari hasil wawancara dan FGD tersebut memberikan rekomendasi bahwa perlunya sebuah asessment yang efektif dan efisien dalam proses pembelajaran jaringan komputer, sehingga perlu adanya analisis terhadap asessment yang telah ada. Hasil FGD juga merumuskan bagaimana memasukkan unsur teknologi dalam proses penilaian. Berdasarkan analisis terhadap kurikulum dan authentic asessment yang diterapkan pada uji eksperimen,

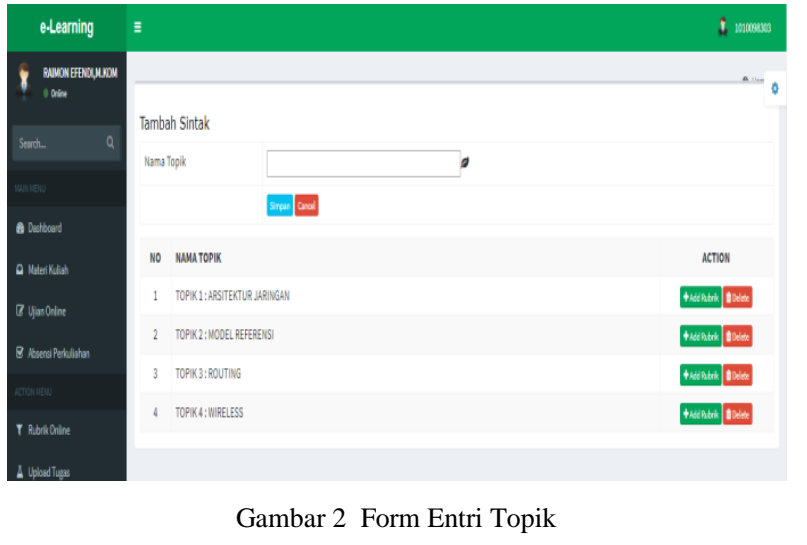




\section{Master Entri Rubrik}

Setelah topik ditetapkan, pada masing-masing topik akan terdapat beberapa rubrik penilaian, rubrik ini dikategorikan sebagai rubrik kinerja, rubrik kompetensi dan rubric praktikum, hal ini sesuai dengan konsep model competency based learning. Entri Master rubric ini terdiri dari komponen dan sub komponen rubrik, seperti terlihat pada gambar 3 .

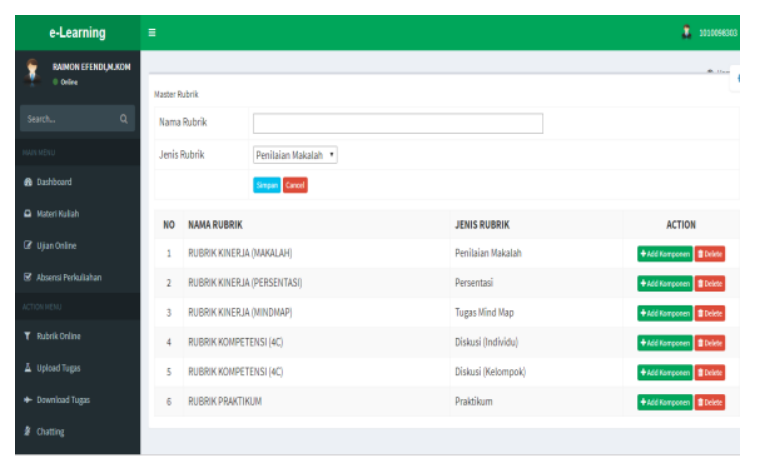

Gambar 3 Form Input Master Rubrik

Penilaian dalam mata kuliah jaringan komputer menggunakan rubric ini dilakukan melalui rangkaian penilaian proses pembelajaran yang dilalui mahasiswa. setiap rubrik diisi penilainnya berdasarkan kegiatankegiatan yang dilakukan.

Hasil Rekap nilai akhir sudah bisa dilihat pada sistem dengn klik "print". Pada printout ini sudah bisa dilihat akumulasi seluruh nilai yang didapatkan mahasiswa selama 1 (satu ) semester, Form ini juga menampilkan rincian dan laporan nilai akhir mahasiswa. Seperti terlihat pada gambar 4 .

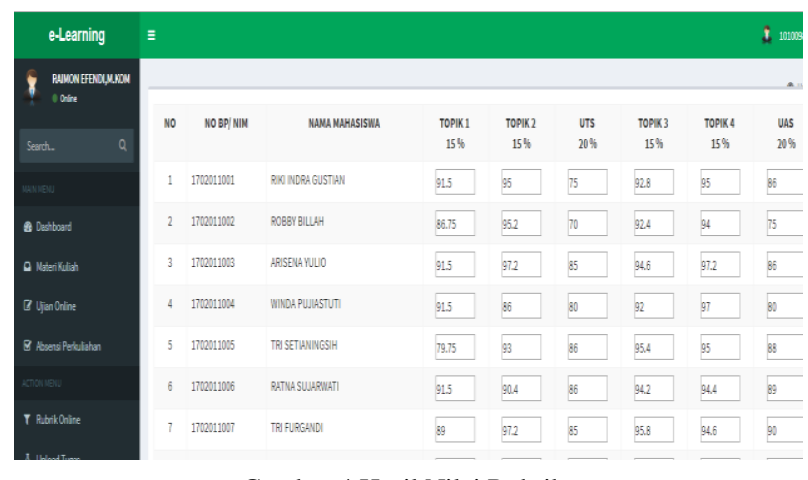

Gambar 4 Hasil Nilai Rubrik

\subsection{Uji Validitas E-Authentic Asessment}

Pada tahap pengembangan ini, tujuannya adalah untuk memperoleh penilaian authentic asessment yang valid. Data uji validitas diperoleh dari tanggapan validator tentang validitas e-authentic asessment. Pada tahap validasi ini, penilaian menggunakan e-authentic asessment pada pembelajaran Jaringan Komputer mengalami beberapa peningkatan berdasarkan saran dari validator yang dianggap penting, seperti terlihat pada tabel 1 .
Tabel 1 Hasil Penilaian validator terhadap RPS

\begin{tabular}{|c|c|c|c|c|c|c|}
\hline \multirow[t]{2}{*}{ Aspek } & \multicolumn{3}{|c|}{ Penilaian Validator } & \multirow[t]{2}{*}{$\sum \mathrm{s}$} & \multirow{2}{*}{$\begin{array}{l}\text { Aiken's } \\
\text { V }\end{array}$} & \multirow[t]{2}{*}{ Hasil } \\
\hline & 1 & 2 & 3 & & & \\
\hline Item 1 & 5 & 5 & 5 & 12 & 0.750 & Valid \\
\hline Item 2 & 5 & 5 & 5 & 12 & 0.750 & Valid \\
\hline Item 3 & 5 & 5 & 5 & 12 & 0.750 & Valid \\
\hline Item 4 & 4 & 4 & 4 & 9 & 0.563 & Invalid \\
\hline Item 5 & 4 & 4 & 4 & 10 & 0.625 & Valid \\
\hline Item 6 & 5 & 5 & 5 & 12 & 0.750 & Valid \\
\hline Item 7 & 4 & 5 & 5 & 11 & 0.688 & Valid \\
\hline Item 8 & 5 & 4 & 4 & 10 & 0.625 & Valid \\
\hline Item 9 & 5 & 5 & 5 & 12 & 0.750 & Valid \\
\hline Item 10 & 5 & 4 & 4 & 10 & 0.625 & Valid \\
\hline Rata-rata & 5 & 5 & 5 & 11 & 0.708 & valid \\
\hline
\end{tabular}

Validasi e-authentic assesment dilakukan oleh tiga validator. Validator 1 memberikan skor rata-rata 5, Validator 2 memberikan skor rata-rata 5, Validator 3 memberikan skor rata-rata 5 . Dari Tabel 2 hasil validasi ketiga validator menghasilkan nilai validasi 0.716 dengan kategori valid.

Tabel 2 Hasil Penilaian validator terhadap E-Authentic Asessment

\begin{tabular}{|c|c|c|c|c|c|c|c|}
\hline \multirow[t]{2}{*}{ No } & \multirow[t]{2}{*}{ Aspect } & \multicolumn{3}{|c|}{$\begin{array}{l}\text { Judgment } \\
\text { Validator }\end{array}$} & \multirow[t]{2}{*}{$\sum \mathrm{s}$} & \multirow{2}{*}{$\begin{array}{l}\text { Aiken's } \\
\text { V }\end{array}$} & \multirow[t]{2}{*}{ Result } \\
\hline & & 1 & 2 & 3 & & & \\
\hline \multirow[t]{4}{*}{$\mathrm{A}$} & Item 1 & 4 & 5 & 4 & 10 & 0.625 & Valid \\
\hline & Item 2 & 5 & 4 & 5 & 11 & 0.688 & Valid \\
\hline & Item 3 & 5 & 4 & 5 & 11 & 0.688 & Valid \\
\hline & Item 4 & 5 & 5 & 4 & 12 & 0.750 & Valid \\
\hline \multirow[t]{6}{*}{ B } & Item 1 & 5 & 5 & 4 & 12 & 0.750 & Valid \\
\hline & Item 2 & 5 & 4 & 5 & 11 & 0.688 & Valid \\
\hline & Item 3 & 5 & 5 & 5 & 12 & 0.750 & Valid \\
\hline & Item 4 & 5 & 5 & 5 & 12 & 0.750 & Valid \\
\hline & Item 1 & 5 & 5 & 5 & 12 & 0.750 & Valid \\
\hline & Item 2 & 5 & 5 & 5 & 12 & 0.750 & valid \\
\hline \multirow[t]{3}{*}{$\mathrm{C}$} & Item 3 & 5 & 4 & 5 & 11 & 0.688 & valid \\
\hline & Item 4 & 5 & 5 & 5 & 12 & 0.750 & valid \\
\hline & Item 5 & 5 & 4 & 5 & 11 & 0.688 & valid \\
\hline
\end{tabular}

\subsection{Implementasi E-Authentic Asessment}

Tahap ini bertujuan untuk memperoleh hasil praktikalitas dan efektivitas dari penerapan e-authntic asessment. Penilaian autentik yang telah disempurnakan berdasarkan pengujian ahli kemudian diuji. Tes otentik penilaian pembelajaran dimulai dengan memberikan pretest. Data pretest dianalisis dan kemudian mahasiswa diundang untuk menggunakan penilaian otentik. Akhirnya para siswa diberikan posttest. Untuk mengidentifikasi informasi penting yang ada dalam penelitian ini. metode wawancara setelah mengikuti pembelajaran digunakan.

Penelitian ini juga bertujuan untuk menentukan efektivitas penilaian otentik. Berikut ini adalah deskripsi uji prkatikalitas dan efektivitas.

\section{Uji praktikalitas $e$-authentic assessment}

Uji praktikalitas e-authentic asessment dilakukan pada dosen. Analisis hasil praktis dosen pada penilaian otentik dapat dilihat pada tabel 3 yang menampilkan hasil penilaian praktis setiap penilaian otentik dilihat dari aspek praktis masing-masing praktisi. 
Tabel 3 Uji Praktikalitas RPS dan Instrumen Asessment

\begin{tabular}{cccc}
\hline No & Praktisi & \multicolumn{2}{c}{ Practical value (\%) } \\
\cline { 3 - 4 } & & RPS & E-Aut Ass \\
\hline 1 & Praktisi 1 & 95 & 94 \\
2 & Praktisi 2 & 95 & 88 \\
3 & Praktisi 3 & 90 & 91 \\
\hline & Rata-Rata & 93 & 91 \\
\hline
\end{tabular}

Pada Tabel 3, dapat dilihat bahwa nilai rata-rata setiap instrumen penilaian e-authentic asesmment berkisar dari 91 hingga 93 yang dapat dikategorikan sebagai sangat praktis. Berdasarkan saran dari dosen yang mengampu mata kuliah Jaringan Komputer di Fakultas Ilmu Komputer, Universitas Dharmas Indonesia, instrumen E-Authentic assessment dapat digunakan dalam pembelajaran sehari-hari, dan dapat digunakan sebagai panduan dalam mengembangkan instrumen pada bahan ilmu komputer lainnya yang memiliki karakteristik yang sama.

\section{Uji efektivitas E-Authentic assessment}

Efektivitas penggunaan E-Authentic assessment dalam pembelajaran jaringan komputer untuk mengukur keterampilan mahasiswa ditinjau dalam dua cara, yaitu dengan melihat pencapaian skor minimum secara klasik bersama dengan diagram yang disajikan menggunakan time series dan dengan menghitung data pretest dan posttest menggunakan skor yang diperoleh dari analisis tes.

5. Efektivitas berdasar kriteria penguasaan minimum secara klasikal dengan metode time series.

Ketuntasan klasikal dengan metode time series bisa dilihat pada nilai rata-rata mahasiswa selama 4 kali tatap muka sebelum menggunakan instrumen E-authentic assesment dibandingkan dengan nilai peserta didik setelah menggunakan intrumen E-Authentic Assesment. Panduan untuk
menentukan ketuntasan mahasiswa adalah dengan membandingkan nilai terhadap nilai minimal yang telah ditentukan.

Nilai yang digunakan adalah nilai dari hasil tes setiap pertemuan yang dilakukan proses pembelajaran empat kali sebelum dan empat kali setelah menggunakan intrumen Authentic Assesment. Hasil tes peserta didik kemudian diberikan nilai dengan ketentuan yang telah ditetapkan, nilai tersebut dibandingkan dengan nilai minimal untuk mata kuliah jaringan komputer yaitu 75. Perbandingan nilai peserta didik secara keseluruhan dengan perhitungan time series dapat dilihat pada tabel 4.

Tabel 4 Perbandingan Nilai Mahasiswa dengan Time Series

\begin{tabular}{crcrrr}
\hline $\begin{array}{c}\text { Pre- } \\
\text { test }\end{array}$ & $\begin{array}{r}\text { rata- } \\
\text { rata }\end{array}$ & Ket & $\begin{array}{c}\text { Post- } \\
\text { test }\end{array}$ & $\begin{array}{c}\text { Rata- } \\
\text { rata }\end{array}$ & Ket \\
\hline Pre $_{1}$ & 71.27 & Tidak tuntas & Post $_{1}$ & 82.41 & Tuntas \\
$\mathrm{Pre}_{2}$ & 71.18 & Tidak tuntas & Post $_{2}$ & 82.41 & Tuntas \\
$\mathrm{Pre}_{3}$ & 71.50 & Tidak tuntas & Post $_{3}$ & 82.41 & Tuntas \\
$\mathrm{Pre}_{4}$ & 72.41 & Tidak tuntas & Post $_{4}$ & 82.41 & Tuntas \\
\hline
\end{tabular}

Berikut nilai hasil pretest dan posttest pada Tabel 4 dapat disajikan pada gambar 4.

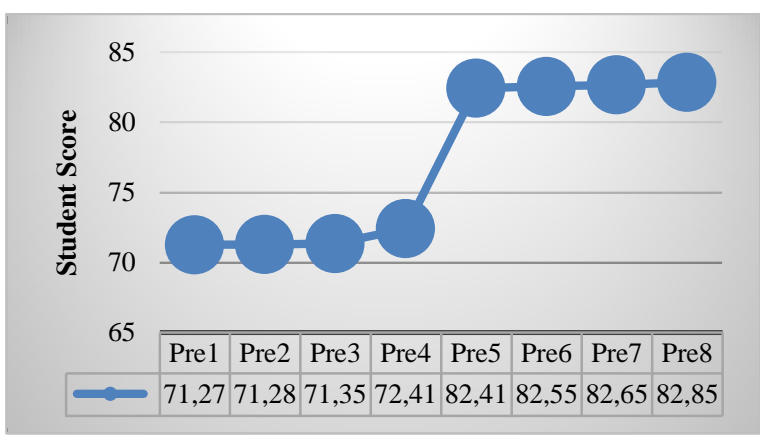

Gambar 1 Tampilan Data Pretest dan Posttest

Sesuai hasil analisis data maka didapatkan hasil perlakuan yang baik, dimana pretes menunjukan keadaan kelompok stabil dan konsisten $(\mathrm{O} 1=\mathrm{O} 2=\mathrm{O} 3=\mathrm{O} 4)$, setelah diberi perlakuan, keadaannya meningkat konsisten $(\mathrm{O} 5=\mathrm{O} 6=\mathrm{O} 7=\mathrm{O} 8)$. Hasil pre-test yang baik adalah $(\mathrm{O} 1=\mathrm{O} 2=\mathrm{O} 3=\mathrm{O} 4)$, dan hasil post-test yang baik adalah $(\mathrm{O} 5=\mathrm{O} 6=\mathrm{O} 7=\mathrm{O} 8)$. Besarnya pengaruh perlakuan adalah $(\mathrm{O} 5=\mathrm{O} 6=\mathrm{O} 7=\mathrm{O} 8)$ $-(\mathrm{O} 1=\mathrm{O} 2=\mathrm{O} 3=\mathrm{O} 4)$

Berdasarkan hasil penelitian maka didapatkan hasil perlakuan baik (Pre1=Pre2=Pre3=Pre4) dan hasil perlakuan yang baik yaitu (Post $1=$ Post $2=$ Post $3=$ Post 4 ). Hasil pretes menunjukan keadaan kelompok stabil dan konsisten, setelah diberi perlakuan keadaannya meningkat konsisten. Hasil perhitungan besar perlakuan mahasiswa terdapat pada Tabel berikut 5 .

Besarnya pengaruh perlakuan adalah: (Post1=Post2=Post3=Post4)-(Pre1=Pre2=Pre3=Pre4),

sehingga presentase minimal ketuntasan mahasiswa adalah: 38\%. Hasil Uji lapangan dapat dilihat pada tabel 5 .

\begin{tabular}{|c|c|c|c|c|c|c|}
\hline No & $\begin{array}{l}\text { Pre- } \\
\text { test }\end{array}$ & $\begin{array}{l}\text { Rata- } \\
\text { rata }\end{array}$ & $\begin{array}{l}\text { Post- } \\
\text { test }\end{array}$ & $\begin{array}{l}\text { Rata- } \\
\text { rata }\end{array}$ & $\begin{array}{l}\text { Pengaruh } \\
\text { Perlakuan }\end{array}$ & $(\%)$ \\
\hline 1 & $\mathrm{Pre}_{1}$ & 71.27 & Post $_{1}$ & 82.41 & 0.39 & $39 \%$ \\
\hline 2 & $\mathrm{Pre}_{2}$ & 71.18 & Post $_{2}$ & 82.41 & 0.39 & $39 \%$ \\
\hline 3 & $\mathrm{Pre}_{3}$ & 71.50 & Post $_{3}$ & 82.41 & 0.38 & $38 \%$ \\
\hline 4 & $\mathrm{Pre}_{4}$ & 72.41 & Post $_{4}$ & 82.41 & 0.36 & $36 \%$ \\
\hline \multicolumn{5}{|c|}{ Rata-Rata } & 0.38 & $38 \%$ \\
\hline
\end{tabular}

6. Efektivitas ditinjau dari perbedaan hasil uji gain score.

Uji gain score untuk melihat peningkatan hasil belajar mahasiswa dari nilai pre-test dan post-test. Hasil analisis data hasil belajar mahasiswa menggunakan authentic assesment menggunakan uji gain score didapat nilai 0.38 kategori sedang. Dengan demikian dapat disimpulkan bahwa authentic assesment dalam pembelajaran Jaringan Komputer untuk mengukur keterampilan mahasiswa efektif untuk digunakan. 


\subsection{Tahap Evaluasi}

Tahap ini menjelaskan evaluasi dari pengembangan produk yaitu E-authentic assesment dalam pembelajaran jaringan komputer. Evaluasi dilakukan mulai dari tahap define, design, develop, dan dissemination. Evaluasi ini menghasilkan revisi-revisi produk yang berfungsi untuk penyempurnaan produk yang dikembangkan.

3.5 E-Authentic Asessmen pada pembelajaran jaringan komputer

Pembelajaran jaringan komputer dilakukan dalam bentuk teoritis dan praktis sehingga kompetensi yang diperoleh dapat digunakan setelah lulus nanti. Sebelum melakukan proses pembelajaran, dosen harus menyiapkan instrumen penilaian terlebih dahulu. Instrumen penilaian memainkan peran penting dalam keberhasilan proses. Oleh karena itu pengembangan $e$ authentic asessment cukup potensial untuk memenuhi tuntutan penilaian dalam pembelajaran. Keuntungan dari e-authentic asessment adalah dapat mengukur keterampilan mahasiswa, dan memberikan kesempatan bagi mahasiswa untuk belajar secara mandiri. Instrumen $e$-authentic asessment yang dikembangkan diharapkan menjadi contoh bagi dosen dalam membuat instrumen e-authentic asessment. Penelitian dan pengembangan instrumen e-authentic asessment menggunakan model $4 \mathrm{D}$, yang terdiri dari 4 tahap, dimana tujuan semua tahap adalah untuk mendapatkan instrumen $e$-authentic asessment yang valid, praktis dan efektif. Instrumen disediakan dalam bentuk web, ini dilakukan untuk merampingkan proses penilaian yang dilakukan oleh dosen. Instrumen $e$-authentic asessment yang telah dikembangkan, divalidasi dan direvisi telah dibuat menjadi buku $e$-authentic asessment yang tidak diterbitkan.

Pada tahap analisis beberapa kegiatan dilakukan, yaitu analisis kurikulum, analisis materi, dan analisis mahasiswa. Tahap ini dilakukan sebagai dasar untuk mengembangkan e-authentic asessment pada mata pelajaran jaringan komputer sehingga dapat digunakan untuk memfasilitasi mahasiswa untuk belajar secara mandiri. Setelah melakukan fase analisis, penilaian otentik diperoleh yang menyajikan 2 topik pembelajaran. Setelah penilaian otentik dikembangkan, validitas, kepraktisan, dan efektivitas produk kemudian diuji.

3.6. Instrumen validitas penilaian otentik

Pengembangan instrumen penilaian otentik sangat mendukung pelaksanaan penilaian dalam pembelajaran. Instrumen otentik yang digunakan oleh penilaian harus valid, sehingga dapat digunakan dalam proses kegiatan belajar mengajar. Validasi otentik dilakukan oleh tiga validator. Validator 1 memberikan peringkat rata-rata 5 dalam kategori yang valid. Validator 2: 5 dalam kategori yang valid. Validator 3: 5 dalam kategori yang valid. Validasi instrumen penilaian otentik dilakukan sekali, di mana masih ada beberapa kekurangan dari instrumen penilaian e-otentik yang dibuat. Selanjutnya, instrumen penilaian otentik dikoreksi sesuai dengan saran dari validator. Hasil validasi instrumen penilaian otentik oleh validator memperoleh instrumen penilaian otentik dengan kategori yang valid dengan nilai $\mathrm{V}$ Aiken 0,708 untuk RPS dan dengan nilai Aiken V sebesar 0,716 untuk penilaian otentik.

\subsection{Instrumen penilaian otentik kepraktisan}

Kepraktisan instrumen e-authentic asessment diperoleh dari hasil analisis kuesioner dosen. Hasil Praktisitas RPS \& e-authentic asessment oleh Dosen, diperoleh nilai rata-rata dari setiap instrumen e-authentic asessment mulai dari 91-93 yang dapat dikategorikan sangat praktis. Berdasarkan hasil tanggapan dosen, ditemukan bahwa instrumen penilaian e-authentic praktis digunakan dan dapat mengukur keterampilan mahasiswa. Kegiatan pembelajaran dan penilaian yang dilakukan dapat menarik minat belajar mahasiswa, sehingga proses pembelajaran interaktif dilakukan. Instrumen penilaian otentik ini dibuat juga dapat digunakan dalam kegiatan pembelajaran sehari-hari sebagai panduan untuk mengembangkan instrumen pada bahan jaringan lainnya.

3.8 Efektivitas instrumen e-authentic asessment

Efektivitas e-authentic asessment dalam penelitian ini terlihat dari kemampuan untuk mengaktifkan mahasiswa dalam belajar dan memfasilitasi pemahaman penilaian dalam pembelajaran. Dalam penilaian ini, efektivitas penilaian otentik dapat dilihat dari segi hasil belajar mahasiswa. Tes digunakan untuk menentukan efektivitas proses pembelajaran. Hasil belajar adalah kemampuan yang dimiliki mahasiswa setelah mereka melalui proses pengalaman belajar. Pengalaman belajar adalah kegiatan belajar yang efektif dan dapat mewujudkan hasil belajar yang baik. Tujuan dari penilaian hasil belajar adalah untuk mengukur seberapa sukses proses belajar mengajar.

Efektivitas instrumen penilaian otentik terbukti melalui uji skor gain dimana nilainya 0,38 dengan kategori sedang, sehingga dapat disimpulkan bahwa instrumen penilaian otentik dalam pembelajaran jaringan komputer untuk mengukur keterampilan mahasiswa dapat dikatakan efektif. Dengan demikian hasil penelitian menunjukkan bahwa penilaian otentik dalam pembelajaran jaringan komputer yang dikembangkan adalah instrumen penilaian otentik yang valid, praktis dan efektif digunakan dalam kegiatan belajar mengajar.

\section{Kesimpulan dan Saran}

\subsection{Kesimpulan}

Kesimpulan dari hasil studi "Pengembangan penilaian E-Authentic Asessment berbasis problem based learning dalam pembelajaran jaringan komputer": 
1. Mengembangkan instrumen penilaian otentik ini kasih kepada Universitas Negeri Padang dan menggunakan metode 4D dengan menganalisis Universitas Dharmas Indonesia atas bantuan dan kurikulum, persyaratan materi dan mahasiswa kerjasama selama penelitian.

dalam pembelajaran jaringan komputer untuk mengukur kompetensi mahasiswa.

2. Instrumen penilaian otentik dalam pembelajaran jaringan komputer untuk mengukur kompetensi mahasiswa yang dikembangkan memenuhi kriteria Valid, hal ini dibuktikan dengan menyelesaikan tahap penilaian yang diberikan oleh dosen ahli untuk menghasilkan instrumen penilaian otentik yang valid. Memenuhi kriteria praktis, dibuktikan dengan nilai praktis yang diberikan oleh dosen dalam kategori yang sangat praktis. Dan memenuhi kriteria efektif, aspek efektivitas ditemukan dalam hasil analisis hasil belajar mahasiswa menggunakan time series dan skor perolehan tes.

\section{Daftar Rujukan}

[1] R. Efendi, A. Yulastri, and Yusran, "Implementation Competency Based Learning Model Of Learning Computer Network Courses At Vocational Education," J. Adv. Res. Dyn. Control Syst., vol. 11, no. 5, pp. 501-505, 2019.

[2] Basuki, Ismet, and Hariyanto, Asesmen Pembelajaran. Bandung: PT. Remaja Rosdakarya, 2014.

[3] T. Palm and E. Boström, "A professional development program in formative assessment for mathematics teachers Which changes did the teachers do and why? To cite this version : HAL Id : hal-01289661 A professional development program in formative assessment for mathematics teach," 2016.

3. Hasil uji efektivitas menunjukkan bahwa terdapat perkembangan kompetensi didik dalam pembelajaran jaringan komputer ketika menggunakan penilaian e-authentic aessment berbasis problem based learning.

[4] S. N. Chang and M. H. Chiu, "The development of authentic assessments to investigate ninth graders' scientific literacy: In the case of scientific cognition concerning the concepts of chemistry and physics," Int. J. Sci. Math. Educ., vol. 3, no. 1, pp. 117-140, 2005.

[5] A. Brown, S. R. Kirpal, and F. Rauner, Identities at Work. Springer Netherlands, 2007.

[6] N. V. Lomovtseva, "Roles of VET in generating a new entrepreneur increative economy sector," 3rd Int. Conf. Vocat. Educ. Train., 2014.

\subsection{Saran}

Penelitian pengembangan telah menghasilkan instrumen penilaian e-authentic yang valid, praktis dan efektif. penilaian otentik pembelajaran jaringan komputer dapat digunakan sebagai sumber penilaian bagi dosen dan mahasiswa dalam pembelajaran. Berdasarkan tes validitas dan kepraktisan, semua pernyataan tentang indikator yang dikembangkan direspon secara positif oleh para ahli dan dosen. Ini menunjukkan bahwa penilaian otentik yang dikembangkan dapat digunakan dalam melaksanakan kegiatan belajar mengajar. Selain itu, ini dapat membantu dosen mengembangkan strategi penilaian dalam upaya membantu mahasiswa menjadi lebih kreatif dan inovatif.

Saran untuk peneliti berikutnya adalah Melakukan studi yang lebih mendalam tentang penilaian otentik dalam pembelajaran yang dikembangkan penilaian e-autentik dapat digunakan dalam melaksanakan kegiatan belajar mengajar. Selain itu, ini dapat membantu dosen mengembangkan strategi penilaian dalam upaya membantu mahasiswa menjadi lebih kreatif dan inovatif.

\section{Ucapan Terimakasih}

Penyelesaian penelitian ini tidak lepas dari dukungan berbagai pihak. Oleh karena itu, penulis mengucapkan terima kasih kepada Lembaga Penguatan Direktorat Penelitian dan Pengembangan Kementerian Riset, Teknologi, dan Pendidikan Tinggi Republik Indonesia yang telah memberikan hibah penelitian magister

[7] A. Edmond, A. Oluniyi, and O. Bamidele, "Re-Engineering Technical Vocational Education And Training ( TVET ) Towards Safety Practice Skill Needs Of Sawmill Workers Against Workplace Hazards In Nigeria .," J. Educ. Pract., vol. 5, no. 7, pp. 150-157, 2014.

[8] O. Oji Kennedy, "Philosophical and Sociological Overview of Vocational and Technical Education in Nigeria," Int. J. Acad. Res. Bus. Soc. Sci., vol. 01, 2011.

[9] H. Usman, Kepemimpinan pendidikan kejuruan. Yogyakarta: UNY Press, 2016.

[10] F. Musa, N. Mufti, R. A. Latiff, and M. M. Amin, "Projectbased Learning (PjBL): Inculcating Soft Skills in 21st Century Workplace," Procedia - Soc. Behav. Sci., vol. 59, no. 2006, pp. 565-573, 2012.

[11] Rustaman and N. Y, "Penilaian Otentik (Authentic Assessment)," pp. 1-18, 2013.

[12] Karen Walstra, "Critical Thinking - making it work in your classroom," 2013.

[13] A. Y. Raimon Efendi, "Effectiveness of Collaborative Problem Based Learning Model of Learning Computer Network Courses BT - 5th UPI International Conference on Technical and Vocational Education and Training (ICTVET 2018)," in 5th UPI International Conference on Technical and Vocational Education and Training (ICTVET 2018), 2019.

[14] J. Larmer, J. Mergendoller, and S. Boss, "Gold Standard PBL: Essential Project Design Elements," Buck Inst. Educ., pp. 1-4, 2015.

[15] A. Majid, Penilaian Autentik Proses dan Hasil Belajar. PT. Remaja Rosdakarya, 2015.

[16] A. Oosterhof, Developing and Using Classroom Assessments. Pearson Education, 2014.

[17] S. I. Ambiyar, Yondri Surfa, Dedy Irfan, Mahesi, "Evaluation of Packet Tracer Application Effectiveness in Computer Design Networking Subject," Int. J. Adv. Sci. Eng. Inf. Technol., vol. 9, no. 1, p. 54, 2019.

[18] R. I. Arends, Learning to Teach (Ten Edition). Jakarta: McGraw-Hill Education, 2014

[19] J. Mueller, "The Authentic Assessment Toolbox : Enhancing Student Learning through Online Faculty Development," Merlot J. Online Learn. Teach., vol. 1, no. 1, p. 7, 2016. 